\title{
INVESTIGATION ON EFFECT OF WELDING CURRENT AND POST WELD HEAT TREATMENT ON MECHANICAL PROPERTIES OF WELDMENT OF LOW CARBON STEEL
}

\author{
Merchant Samir $\mathbf{Y}^{1}$ \\ ${ }^{1}$ Lecturer, Fabrication Technology Department, Sir. B.P. Institute, Bhavnagar, Gujarat, India. \\ symerchant72@gmail.com
}

\begin{abstract}
Welding is one of the major metal joining process widely used in process equipment fabrication industry. In this paper effect of process variable and post weld heat treatment temperature on mechanical properties of weld joint is investigated. Different weld joints are welded with different welding current. The weld specimens of $10 \mathrm{~mm}$ thickness were welded at $80 \mathrm{~A}, 90 \mathrm{~A}$ and $100 \mathrm{~A}$ with arc voltage $25 \mathrm{~V}$ using E-6013 electrode with DCEP polarity. The weldments were then post weld heat treated by setting PWHT cycle as per ASME sec VIII Div 1 UCS 56 at different temperature $600{ }^{\circ} \mathrm{C}, 675{ }^{\circ} \mathrm{C}$ and $750{ }^{\circ} \mathrm{C}$. Change in mechanical properties like hardness before and after PWHT was investigated. It was found that with increase in welding current hardness of weld joint decrease due to increase in heat input but it was very high than the unwelded base metal. It was observed that after $P W H T$ below recrystallization temperature (lower critical temperature line- $723^{\circ} \mathrm{C}$ ) hardness of weld metal and fusion boundary region did not change but hardness of HAZ and base metal region decreased with increase in PWHT temperature. When PWHT temperature increased above $723{ }^{\circ} \mathrm{C}$ hardness of all regions of weld joint decreased.
\end{abstract}

Key Word: Weld Joint, HAZ, Hardness, PWHT, Socking Temperature.

\section{INTRODUCTION}

Shielded metal arc welding is one of basic welding process used in process equipment fabrication industry. It is easy to operate and investigated both in industry and laboratory. Different process parameters like welding current, arc voltage, welding speed, cooling rate, weld joint edge preparation, weld metal specification, electrode diameter, base metal thickness, chemical composition of base metal, welding polarity etc. are playing important role on mechanical properties of weldment. Low carbon steel is widely used in process equipment fabrication industry, structural fabrication industry, ship building industry and piping industry. It is easily available in various grades and cheap. It is having very good tensile strength, low hardness and good impact strength properties. During welding heating and cooling of metal is done at very rapid speed. Residual stresses are produced in welding thermal cycle. This produces adverse effect on mechanical properties of low carbon steel. It is difficult to control the heating and cooling rate during welding so we cannot have complete control on the adverse effect on the mechanical properties. This led to failure of weldment into the service. The best method to improve mechanical properties of weld joint is post weld heat treatment. There are many heat treatment processes but for weld joint annealing, normalizing and stress relieving are majorly used. The use of annealing is restricted due to grain growth. This leads to reduction in mechanical strength of weld joint. In process equipment fabrication industry normalizing and stress relieving are widely used. However local stress relieving is done very carefully to avoid uneven heating and overheating. Normalizing produce stress free weld joint with comparatively stable structure[1].

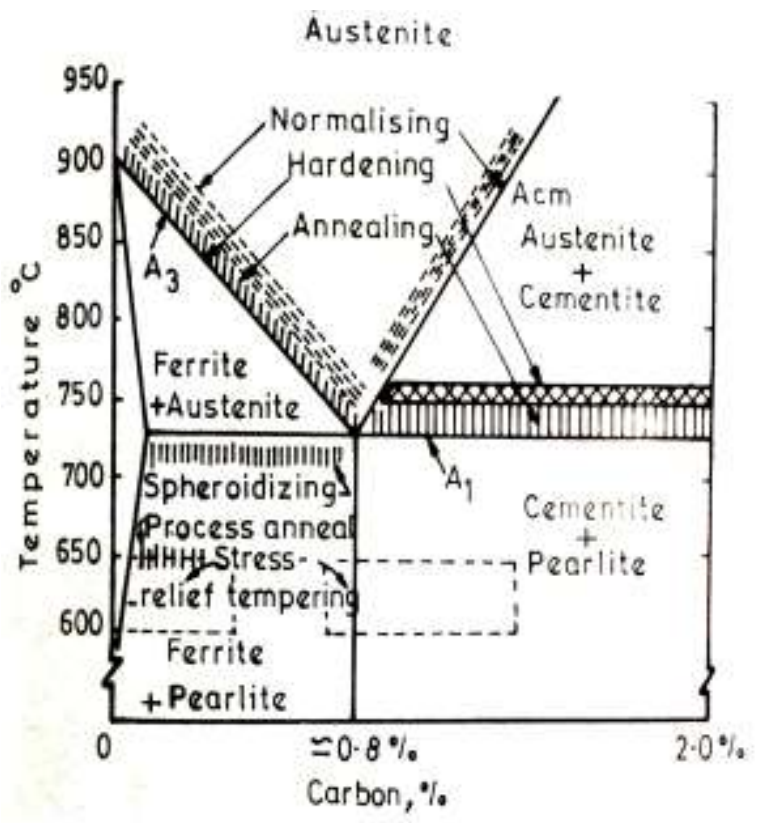

Fig. 1: Heat Treatment Diagram[2].

During PWHT, weld joint is heated up to a specified temperature followed by cooling up to $300{ }^{\circ} \mathrm{C}$ into furnace and then air quenched up to room temperature. This converts martensite into tempered martensite and hence weldment can be cooled upto room temperature without 
danger of crack formation. A sketch of thermal histories of welding and PWHT of heat treatable alloy is shown in fig. 2 . As shown in fig. 2(A) PWHT is carried out immediately after welding is performed. HAZ should be cooled slightly below the martensite finish temperature Mf before starting heating for PWHT. This prevents untransformed austenite from decomposing into ferrite and pearlite during stress relieving heat treatment which may transform into untempered martensite during cooling which is hard and brittle. In case if it is not possible to start PWHT immediately after welding, first weldment is heated upto $400^{\circ} \mathrm{C}$ for 1 hour and then PWHT is started. This convert martensite into bainite, which is more ductile than martensite. Hence problem of delayed cracking or PWHT crack can be avoided [1].
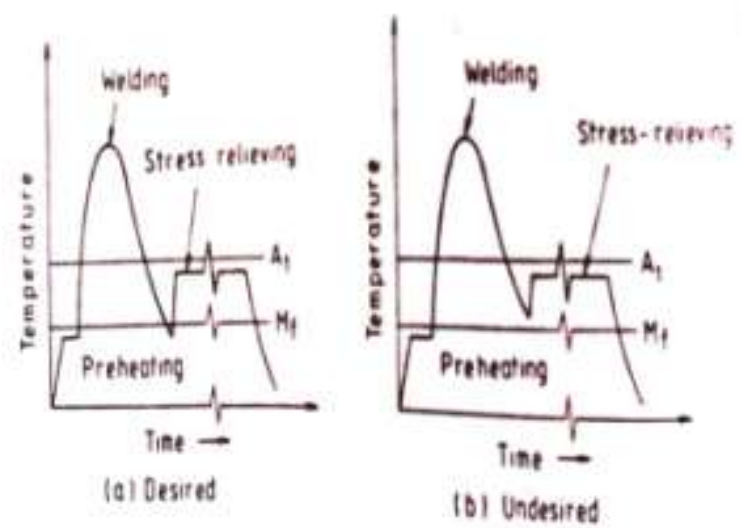

Fig.-2 : Schematic Representation Of (A) Desired And (B) Undesired Thermal Histories For Welding And PWHT For Heat Treatable Steel[1].

PWHT is required to reduce hardness of both weld metal and HAZ. It further results in tempering of base metal whose hardness and mechanical properties are diminished. In PWHT, if temperature is not proper then due to over tempering of base metal carbide re-precipitation occur in weld joint, which increase their grain size and increases ferrite content. This microstrucutral modification may damage the toughness of base metal. It shows poor fracture behavior at low temperature. It was found that if PWHT for a limited time at a temperature higher than the maximum level prescribed for PWHT cause only a limited change in microstructure of ASME SA-542M steel and do not harm base metal, weld metal and HAZ [3]. The effect of PWHT at $750^{\circ} \mathrm{C}$ for 2,4 and 6 hours on microstructure and hardness of weldment of P22 and P91 steel using Inconel 625 filler metal was investigated by Nattaphon Tammasophon, Weerasak Homhrajai and Gobboon Lothongkum. They found that PWHT produce more homogeneous microstructures after welding and reduce hardness differences in welded microstructures, which reduce weld cracking. The most suitable condition for PWHT was at $750^{\circ} \mathrm{C}$ for 2 hours for minimum hardness difference between different zones of weld joint [4]. Increasing the heat input increase the area of weld bead. In multi-run welding higher heat input reduce the columnar structure at solidified weld joint center line. With increase in heat input in welding both hardness and strength reduced
[5]. Creep resistance increased of P91 grade steel weld when heat treated at $600{ }^{\circ} \mathrm{C}$ for 2 hours. Room temperature toughness of HAZ improved only after $720{ }^{\circ} \mathrm{C}$ for 2 hours for PWHT. PWHT temperature above $820{ }^{\circ} \mathrm{C}$ creep strain rate and creep ductility significantly increased. Failure of specimen moved towards weld fusion line. PWHT changes grain size and degree of tempering of martensite. The number and sizes of carbide precipitation were proportional to PWHT time and temperature [6]. With increase in PWHT duration time impact toughness was continuous improved of P91 steel. Hardness and tensile strength decreased with increase in PWHT holding time from 3 hours to 6 hours. Mechanical properties like toughness, ductility and hardness within acceptable limit were obtained only after $760{ }^{\circ} \mathrm{C}$ PWHT temperature for 3 hours period [7]. PWHT is required in steel to produce acceptable mechanical properties of HAZ, minimize risk of hydrogen induced cracking and to minimize welding residual stresses. Microstructure of HAZ is responsible for properties of weld joint and PWHT minimize the risk of cold cracking. Welding stresses can be decreased upto $21-32 \%$ by using parallel heat welding technique [8].

\section{EXPERIMENTAL PROCEDURE}

Material used for experiment was low carbon steel plate of $100 \mathrm{~mm}$ long, $50 \mathrm{~mm}$ width and $10 \mathrm{~mm}$ thickness. Chemical composition of material is represented in table -1 . Total nine specimens were cut from one low carbon steel plate using power hacksaw machine. All nine specimens were cut from one plate so hardness of base metal remains constant for all nine specimens. Then weld joint was made by single $\mathrm{V}$ of 60 degree bevel with $2 \mathrm{~mm}$ root gap and $2 \mathrm{~mm}$ root face. Then hardness of all specimens was measured. For hardness test Rockwell hardness tester was used. Its technical specification is shown in table-3. Then specimens were welded by using SMAW process by using $3.15 \mathrm{~mm}$ diameter and $350 \mathrm{~mm}$ long AWS/SFA 5.1 E-6013 welding electrode. Chemical composition of welding electrode is shown in table-3. Welding polarity was selected DCEP. Welding current varied as $80 \mathrm{~A}, 90 \mathrm{~A}$ and $100 \mathrm{~A}$ and arc voltage 25 volts. Three specimens were welded on current $80 \mathrm{~A}$, three on current $90 \mathrm{~A}$ and remaining three specimens were welded on 100A welding current. Weld specimens were grinded and weld reinforcement was flushed. Hardness of weld joint at each $5 \mathrm{~mm}$ from center line as shown in fig.3 was measured and results were recorded in observation table-5. For PWHT machined weld specimen were put into muffle furnace with electronic timer and digital display panel shown in fig.-4. PWHT cycle was set as per ASME sec VIII div I UCS 56 as shown in table-4 [9]. After PWHT hardness of all specimens were measured at $5 \mathrm{~mm}$ from weld center line and results recorded in table-5.

Table -1 : Chemical Composition Of Base Metal

\begin{tabular}{|c|c|c|c|c|c|}
\hline Element & $\mathrm{C}$ & $\mathrm{Mn}$ & $\mathrm{Si}$ & $\mathrm{S}$ & $\mathrm{P}$ \\
\hline percent & $0.18-$ & $0.70-$ & 0.40 & 0.05 & 0.05 \\
& 0.22 & 0.90 & $\max$ & $\max$ & $\max$ \\
\hline
\end{tabular}


Table - 2 : Technical Specification Of Rockwell Hardness Testing Machine

\begin{tabular}{|l|l|}
\hline Model & TRS \\
\hline Type & Rockwell Hardness Tester \\
\hline Max. Test Height & $216 \mathrm{~mm}$ \\
\hline Throat depth & $133 \mathrm{~mm}$ \\
\hline Make & MCS \\
\hline Capacity & $2500 \mathrm{~N}$ \\
\hline Height & $630 \mathrm{~mm}$ \\
\hline Net Weight & $77 \mathrm{Kgs}$ \\
\hline
\end{tabular}

Table -3 : Chemical Composition of E-6013 Electrode

\begin{tabular}{|c|c|c|c|c|c|}
\hline Element & $\mathrm{C}$ & $\mathrm{Mn}$ & $\mathrm{Si}$ & $\mathrm{S}$ & $\mathrm{P}$ \\
\hline percent & 0.07 & 0.44 & 0.22 & 0.02 & 0.02 \\
\hline
\end{tabular}

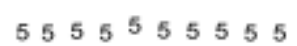

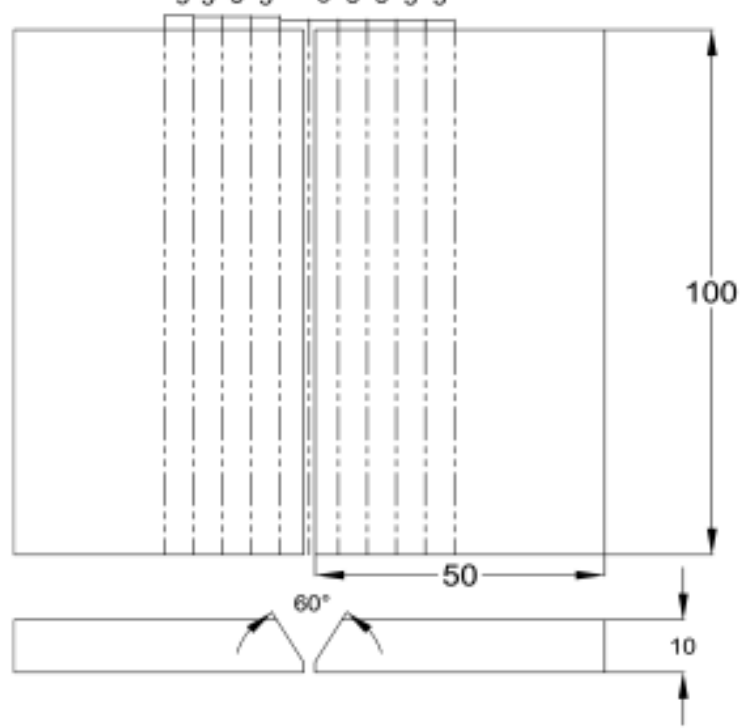

ALL DIMENSIONS ARE IN MM

Fig-3 : Job sketch

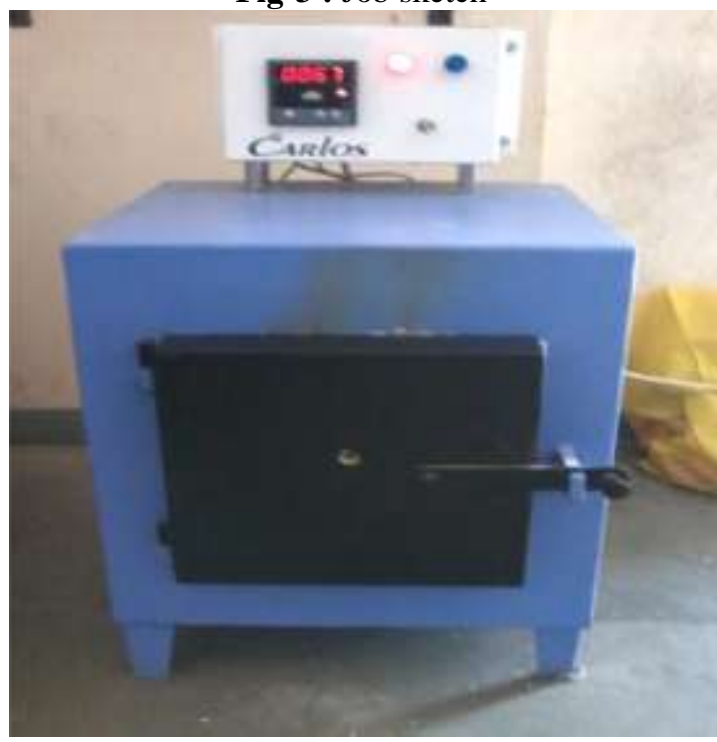

Fig-4 : Heat Treatment Furnace

Table -4 : PWHT Cycle

\begin{tabular}{|c|l|l|l|l|}
\multicolumn{5}{|c|}{ Table -4 : PWHT Cycle } \\
$\begin{array}{r}\text { Sr. } \\
\text { No. }\end{array}$ & Description & PWHT-1 & PWHT-2 & PWHT-3 \\
\hline 1 & Material & $\begin{array}{l}\text { Low } \\
\text { carbon } \\
\text { steel }\end{array}$ & $\begin{array}{l}\text { Low } \\
\text { carbon } \\
\text { steel }\end{array}$ & $\begin{array}{l}\text { Low } \\
\text { carbon } \\
\text { steel }\end{array}$ \\
\hline 2 & Loading temp & $50^{\circ} \mathrm{C}$ & $50^{\circ} \mathrm{C}$ & $50^{\circ} \mathrm{C}$ \\
\hline 3 & Heating Time & $29 \mathrm{~min}$ & $33 \mathrm{~min}$ & $47 \mathrm{~min}$ \\
\hline 4 & Soaking temp & $600^{\circ} \mathrm{C}$ & $675^{\circ} \mathrm{C}$ & $750^{\circ} \mathrm{C}$ \\
\hline 5 & Soaking time & $15 \mathrm{~min}$ & $15 \mathrm{~min}$ & $15 \mathrm{~min}$ \\
\hline 6 & $\begin{array}{l}\text { Cooling Time } \\
\text { (in Furnace) }\end{array}$ & $172 \mathrm{~min}$ & $230 \mathrm{~min}$ & $266 \mathrm{~min}$ \\
\hline 7 & $\begin{array}{l}\text { Unloading } \\
\text { temp }\end{array}$ & $300^{\circ} \mathrm{C}$ & $300^{\circ} \mathrm{C}$ & $300^{\circ} \mathrm{C}$ \\
\hline
\end{tabular}

Table-5 : Observation Table

\begin{tabular}{|c|c|c|c|c|c|c|c|c|c|c|c|c|c|}
\hline \multirow[b]{2}{*}{ Sr. No. } & \multirow{2}{*}{$\begin{array}{l}\text { Welding } \\
\text { Current }\end{array}$} & \multirow[b]{2}{*}{ Condition } & \multicolumn{11}{|c|}{ Hardness value (HRB) from weld center line } \\
\hline & & & -25 & -20 & -15 & -10 & -5 & $\mathbf{0}$ & $\mathbf{5}$ & 10 & 15 & 20 & 25 \\
\hline 1 & \multirow{5}{*}{$80 \mathrm{~A}$} & Before welding & 78 & 78 & 78 & 78 & 78 & 78 & 78 & 78 & 78 & 78 & 78 \\
\hline 2 & & As welded & 78 & 82 & 85 & 86 & 93 & 91 & 96 & 81 & $\$ 1$ & 80 & 81 \\
\hline 3 & & $600 \mathrm{C}$ & 74 & 75 & 77 & 84 & 94 & 93 & 97 & 79 & 77 & 73 & 73 \\
\hline 4 & & $675 \mathrm{C}$ & 73 & 74 & 76 & 83 & 93 & 91 & 96 & 79 & 76 & 72 & 72 \\
\hline 5 & & $750 \mathrm{C}$ & 72 & 73 & 75 & 81 & 89 & 85 & 92 & 77 & 74 & 71 & 71 \\
\hline 6 & \multirow{5}{*}{$90 \mathrm{~A}$} & Before welding & 78 & 78 & 78 & 78 & 78 & 78 & 78 & 78 & 78 & 78 & 78 \\
\hline 7 & & As welded & 81 & 82 & 82 & 84 & 88 & 90 & 91 & 80 & 83 & 84 & 83 \\
\hline 8 & & $600 \mathrm{C}$ & 77 & 76 & 76 & 78 & 88 & 91 & 91 & 77 & 78 & 78 & 77 \\
\hline 9 & & $675 \mathrm{C}$ & 75 & 75 & 74 & 77 & 88 & 90 & 90 & 76 & 77 & 75 & 74 \\
\hline 10 & & $750 \mathrm{C}$ & 73 & 73 & 73 & 79 & 84 & 84 & 87 & 75 & 75 & 72 & 72 \\
\hline 11 & \multirow{5}{*}{$100 \mathrm{~A}$} & Before welding & 78 & 78 & 78 & 78 & 78 & 78 & 78 & 78 & 78 & 78 & 78 \\
\hline 12 & & As welded & 80 & 81 & 82 & 81 & 88 & 89 & 87 & 83 & 83 & 83 & 82 \\
\hline 13 & & $600 \mathrm{C}$ & 74 & 75 & 76 & 78 & 88 & 89 & 87 & 81 & 77 & 76 & 74 \\
\hline 14 & & $675 \mathrm{C}$ & 72 & 73 & 74 & 75 & 88 & 89 & 87 & 80 & 76 & 74 & 72 \\
\hline 15 & & $750 \mathrm{C}$ & 72 & 72 & 73 & 76 & 84 & 84 & 83 & 78 & 75 & 74 & 72 \\
\hline
\end{tabular}

(-ve) left side of weld center line, (+ve) right side of weld center line 


\section{RESULT \& DISCUSSION}

\subsection{Effect of welding current on hardness}

It is very much clear from observation table -5 that with increase in welding current from 80 amp to $100 \mathrm{amp}$ welding heat input is also increase and due to this hardness of weld metal and heat affected zone is decreased as shown in fig-5.

\subsection{Effect of PWHT on hardness of weld joint}
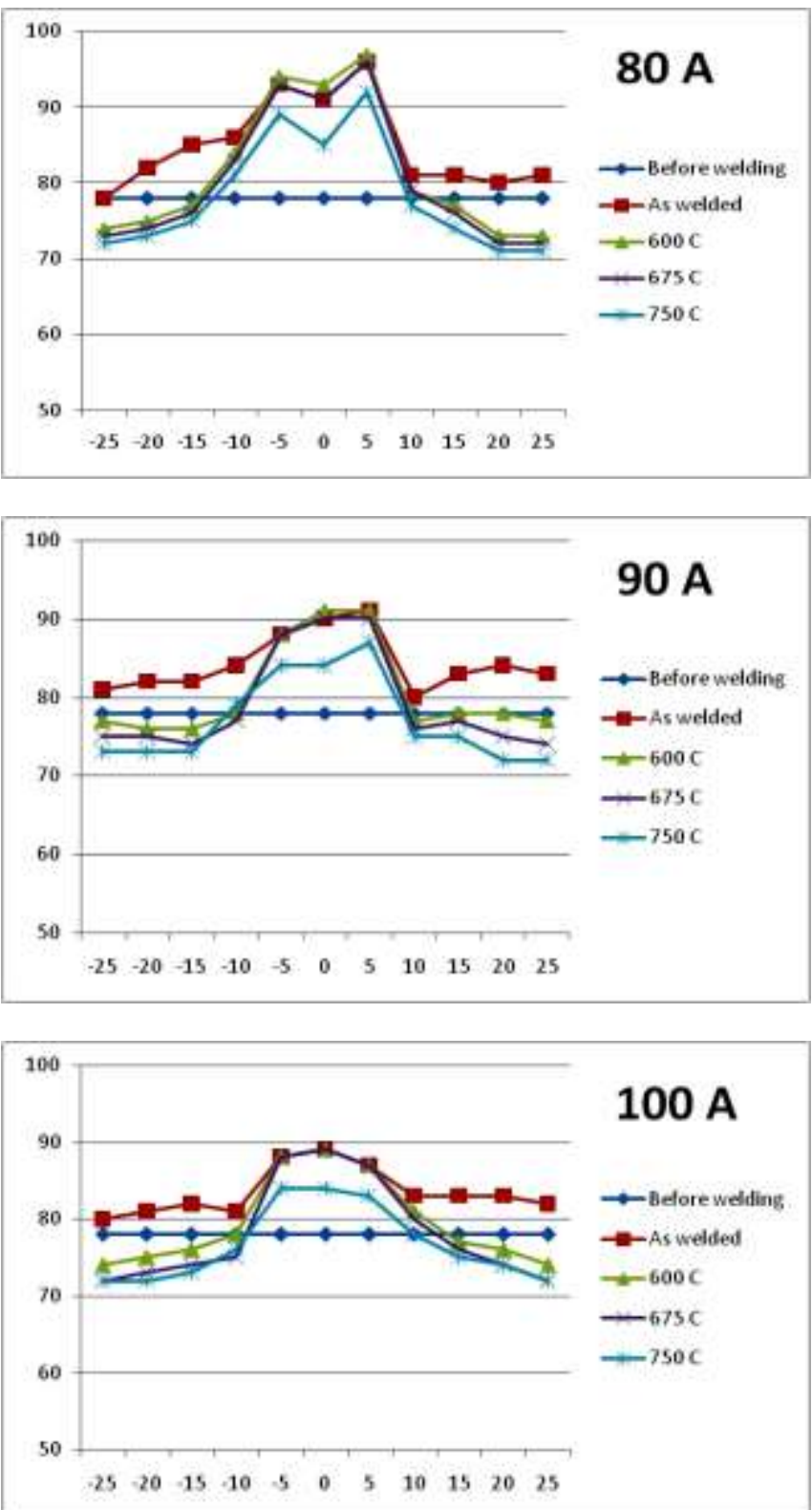

Fig-5 : Effect Of Welding Current And PWHT On Weld Joint

It is clear from observation table-5 and fig. -5 that hardness of all low carbon steel specimen is increased at every region of weld joint i.e. $-25,-20,-15,-10,-5,0,5,10,15,20,25$. Highest hardness was observed at fusion boundary line i.e. -5 and 5 $\mathrm{mm}$ distance from weld center line. The main reason for this is the fastest cooling rate in this region. Hence matensite or bainite formation in the metal is occurred which are hard and brittle. From all three graphs of $80 \mathrm{~A}, 90 \mathrm{~A}$ and $100 \mathrm{~A}$ it is very much clear that distribution of hardness is not uniform throughout the weld joint. This creates non homogeneity in weld joint produce a weak weld joint from strength and corrosion resistance point of view. A huge amount of residual thermal stresses are stored in weld joint and HAZ which is going to be removed or reduced for better performance of weld joint in service. The solution is PWHT. From fig.-5 it is observed that hardness of weld joint is decreased as PWHT temperature increased from $600^{\circ} \mathrm{C}$ to $750^{\circ} \mathrm{C}$
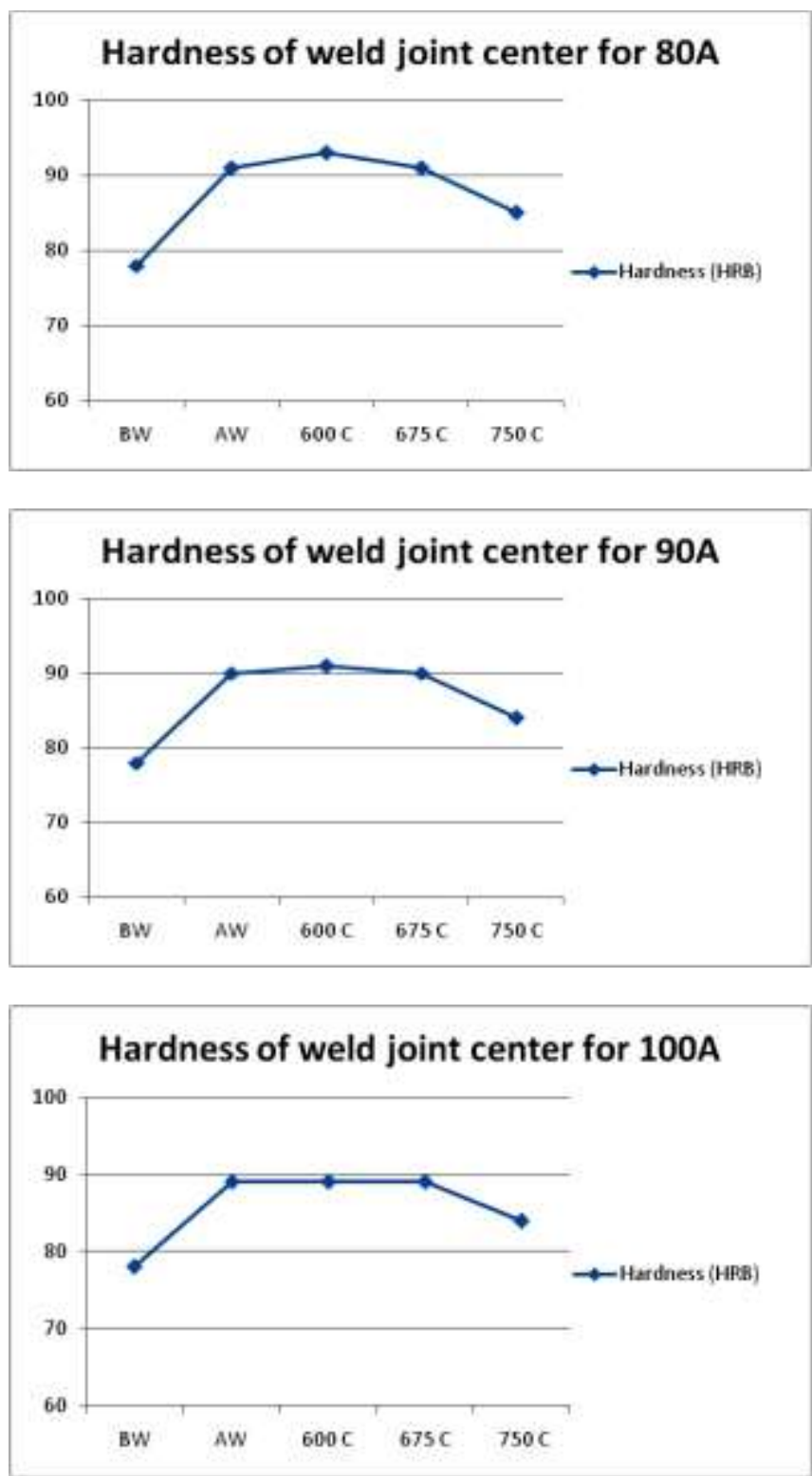

Fig-6 : Effect Of PWHT At Weld Joint Center

From fig.-5 and fig. -6 it is observed that hardness of weld metal at center line is increased slightly after PWHT at $600^{\circ} \mathrm{C}$ for $80 \mathrm{~A}$ and $90 \mathrm{~A}$ specimens. It remains constant 100A specimen. This is because of transformation of ferrite and pearlite into untempered martensite during stress relieving. Hardness remains constant at $675^{\circ} \mathrm{C}$ for all three specimens. Hardness of weld metal at center line decreased marginally at $750^{\circ} \mathrm{C}$ for remaining three specimens. 
Hardness of weld joint upto $10 \mathrm{~mm}$ distance from weld center line in both directions decreased compared to as welded condition but remains higher than the parent metal. Hardness of weld joint away from $10 \mathrm{~mm}$ from weld center line decrease marginally and even less that the parent metal. It is observed from all three PWHT cycle that distribution of hardness during weld joint is becomes more uniform in case of $750^{\circ} \mathrm{C}$ compare to other two PWHT cycle. This is because of heating and socking the specimens above the recrystallization temperature. So grain refinement was occurred in weld joint.

\section{CONCLUSION}

After analyzing observation table-5 and fig. $5 \& 6$ following major conclusions are obtained

1. Hardness of low carbon steel is increases after welding. The increment is not uniform throughout the weld joint. Highest hardness is observed at near fusion boundary region.

2. PWHT reduces hardness of weld joint.

3. With increase in PWHT temperature hardness of weld joint decreases.

4. While socking weld joint at below recrystallization temperature (lower critical temperature line of iron carbon phase diagram- $723^{\circ} \mathrm{C}$ ) hardness of weld metal and fusion boundary region is increasing slightly or it remains constant. So it can be assumed that tensile strength remains constant and toughness may increase due to removal of residual thermal stresses.

5. While heating above recrystallization temperature hardness of weld metal and fusion boundary region decreases rapidly. That shows that joint becomes softer due to grain reformation from martensite or lower bainite to pearlite or acicular ferrite.

6. Hardness of HAZ after $10 \mathrm{~mm}$ from welding center line decreases in all PWHT cycles. It is less than parent metal hardness. With increase in PWHT temperature reduction in hardness is observed in HAZ and parent metal but its rate is decreased.

7. When PWHT socking temperature is above recrystallization temperature distribution of hardness throughout the weld joint becomes more uniform in all regions.

\section{REFERENCES}

[1]. "Welding Engineering And Technology", By Dr. R.S.Parmar, Khanna Publishers, Fifth reprint, 2007.

[2]. "A text book of material science and metallurgy", by Dr. O.P.Khanna, Dhanpat rai publication (p) ltd., tenth reprint 2006.

[3]. R. Roberti, G. Cornacchia, M.Faccoli, "Effect of increasing post weld heat treatment temperature on the fracture toughness of an ASME SA-542M steel" Workshop IGF, Forni di Sopra (UD), Italia, 1-3 marzo 2012, pp 137-143.

[4]. Nattaphon TAMMASOPHON, Weerasak HOMHRAJAI, Gobboon LOTHONGKUM, "Effect of Postweld Heat Treatment on Microstructures and Hardness of TIG,Weldment between P22 and P91
Steels with Inconel 625 Filler Metal " Journal of Metals, Materials and Minerals, Vol.21 No.1 pp.93-99, 2011.

[5]. Enda Keehan, “Effect of Microstructure on Mechanical Properties of High Strength Steel Weld Metals ", ISBN 91 - 7291 - 523 - 4, Printed and bound by Chalmers Reproservice Göteborg, Sweden 2004.

[6]. Dr. Leijun Li, "Effect of Post-Weld Heat Treatment on Creep Rupture Properties of Grade 91 Steel Heavy Section Welds", Mechanical \& Aerospace Engineering, Utah State University (435)797-8184, 2012.

[7]. Devinder Pal Singh, Mithlesh Sharma, Jaspal Singh Gill, "Effect of Post Weld Heat Treatment on the Impact Toughness and Microstructural Property", IJRMET Vol.-3, Issue- 2, May - Oct-2013, pp 216219.

[8]. Som Dutt Sharma, Rati saluja, K M Moeed, "A Review On Effect Of Preheating And/Or Post Weld Heat Treatment (PWHT) On Hardened Steel”, International Journal of Technical Research and Applications, Volume 1, Issue 2 (may-june 2013), PP. 05-07.

[9]. ASME sec VIII Division-1, Boiler And Pressure Vessel Code, 2007 Edition, "Requirement For Post Weld Heat Treatment", pp 159-169.

\section{BIOGRAPHIES}

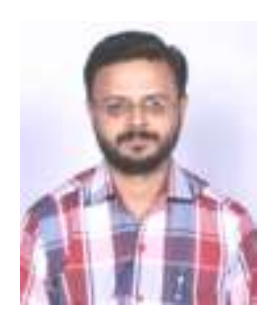

Merchant Samir Y. is working as a senior lecturer in Fabrication Technology Department, Sir Bhavsinhji Polytechnic Institute, Bhavnagar, Gujarat, India since 2004. He obtained M.E. Mechanical Engineering ( Production Engineering) from M.S.Univesity, Vadodara with first rank in 2010. 